\title{
Design of throw-in type rice thresher for small scale farmers
}

\author{
Ouézou Yaovi Azouma ${ }^{1,2}$, Makennibe Porosi ${ }^{1,2}$ and Koji Yamaguchi ${ }^{3}$ \\ ${ }^{1}$ Université de Lomé, Ecole Supérieure d'Agronomie / Département de Génie Rural et Machinisme agricole BP 1515 Lomé, \\ Togo; ${ }^{2}$ Centre de Recherche sur la Mécanisation de l'Agriculture au Togo (CRMAT), BP 1515 ESA/UL Lomé- Togo \\ ${ }^{3}$ Japan Intl. Cooperation Agency / Tsukuba Intl. Center, 3-6 Koyadai, Tsukuba-shi, Ibaraki-Ken 305-0074, Japan \\ azouma@yahoo.com; poromake@yahoo.com; yamaguchi@task-a.jp
}

Abstract: Threshing is an integral part of postharvest activities for cereal and legume crops. In many developing countries, threshing is carried out manually by farmers that lead to low quality of paddy rice and grain loss. When the rice production increases, consequently the manual threshing becomes arduous. In order to mechanize this process, a throw-in type thresher JEP based on a prototype of a thresher made by IRRI (International Rice Research Institute) was designed and tested. The wind board was modified after testing to enhance threshing quality. Also, in place of welding the whole machine is joined by bolts, nuts and rivets for easy assembling and disassembling. Output capacity from the performance test on the machine was $316 \mathrm{~kg} / \mathrm{hr}$ at a moisture content of $21 \% \mathrm{wb}$ (wet base) for IR28 rice variety. This could attain $350-400 \mathrm{~kg} / \mathrm{hr}$ when both, the speed and the feeding speed increase. The overall results are impressive and it will help improve drudgery and threshing challenges with small scale farmers.

Keywords: paddy rice, postharvest, design, thresher JEP Introduction

Rice is a cereal cultivated mainly for the human consumption and also finds use in manufacturing of alcohol, starch, glucose, acetic acid, vinegar, acetone, oil and pharmaceutical products and diet foods. The rice ball is developed like fuel and ashes which are re-used in the form of organic manure (Pirot, 1998). More than $40 \%$ of the rice consumption in West Africa is imported, which represents 2.75 million tons per year (Barris et al., 2005). This strong quantity of imported rice constitutes a significant loss of currencies, more than one million \$US per year according to WARDA'S. Also, the current blaze of the rice prices limits the imports and threatens food security in the countries as Togo whose consumption relies mainly on these imports. In order to bring a response to the current rice crisis, FAO and WARDA launched an emergency initiative on the rice in which Togo takes part in the sides of ten other member states of the WARDA. Irrational harvest and the rudimentary postharvest operations are factors of losses of rice that can reach $35 \%$. The inefficiency of manual threshing and winnowing, seasonal drudgeries of the women and the children in West Africa worsens its losses: damaged and broken grains sensitive to the damage of storage and commercial low value. The policies which promote the local production as well increase the workload of the producers. So manual threshing and winnowing being already arduous require more labour (WARDA, 2005). The extension of the threshing-machines ASI, manufactured in several countries of West Africa: Ghana,
Mali, Senegal, Burkina Faso, Mauritania and Côte d'Ivoire, has reduced the arduousness and has increased the labour capacity (threshing output: 1-2 t/hr). These threshers which cost 2.8-2.9 million francs CFA ( $\sim 5000$ \$US) have a rate of separation grain straw of $99 \%$. According to the conditions of Sub-Saharan Africa where $80 \%$ of the farmers exploit small-scale farms (Bobobee, 1993; Phillip, 1993; Faure, 1994; Anonymous, 1996; 1998 ) and $43 \%$ of the total population live below the poverty line, less than 1.00 \$US per day (Sims \& Kienzle, 2006), the design of a thresher with a mean capacity output was planned. The main objectives of this research work are: to design and evaluate a throw-in type thresher using long grain variety of rice and to increase threshing efficiency while reducing losses. Crossing the specifications of the threshing-machine IRRI with Japanese techniques and specifications given by specialists from Togo, Ghana and Tajikistan, the thresher JEP, light and less expensive was designed. This paper presents the results of the designing, the technical performances and the socio-economical advantages of the thresher JEP.

Materials and methods

Socio-technical and economical context of the study

Drudgery, labour intensiveness, low grain quality and widespread use of simple farm tools which results in low productivity and high postharvest losses are the common features of many developing countries.

Togo: The demand for rice is high while the imports levels become higher than the national production output. From 2000 to 2004, the rice imports in Togo have reached 264576 tons which were in value 13.895 milliard francs CFA (ITRA, 2007). Togo has an enormous potentiality for rice production, in particular the availability of low lands and alluvial plains not yet exploited (Table 1), a favourable pluviometry (900 to $1400 \mathrm{~mm}$ of rain per year), the availability of a range of powerful improved rice seeds adapted to various ecologies: TGR1, TGR34, IR46, IR841, ITA212, MK53-86, NERICA. In regard to the rice crisis (weakness of the national production and rise of the import prices), Togo takes part in the emergency initiative on the rice which will make possible to reduce $17 \%$ of the imports till the end of 2009. This reduction of the imports or in otherwise the increase in $37 \%$ of the current production of paddy rice, represents a saving in currencies of about 13 million \$US. In order to achieve this goal, the Ministry for Agriculture, Livestock and Fishery worked out a strategy of revival of the agricultural production (MAEP, 2008) of which one of the priority actions (Emergency plan 2008-2010) is the required food
Research article

Clndian Society for Education and Environment (iSee)
"Low cost paddy thresher"

http://www.indjst.org
Azouma et al. Indian J.Sci.Technol. 
production and more particularly the revival of the national production of rice. This emergency plan 20082010 , adopted in the Council of Ministers of the $30^{\text {th }}$ July 2008, has to be based on the following actions: a partial support of paddy farming based on small installations, an improvement of the post-harvests operations going from threshing to the transformation by small units, the conditioning, and the trade-circuit.

In the rice farming zones, threshing is often carried out manually with sticks and rammers (output capacity $\leq 1$ ton per day), or is mechanized, carried out with pedal threshers whose output capacity is around 100 to 150 $\mathrm{kg} / \mathrm{hr}$ (Gret et al., 1993; Akintayo et al., 2008). The motorized threshing-machines are practically non-existent on the sites of rice production. From the rice farming under irrigation in the valley of Zio (Fig. 1), we describe the harvest and postharvest systems in Togo.

When rice paddy becomes ripe, harvest occurs after 30-35 days of hunting of birds to reduce the losses of output. Harvest is carried out in general by the women using sickles and knives. The producers carry out harvest when maturity of the rice plant is very well attained that causes spontaneous losses by shelling. Mechanical threshing is carried out with Chinese pedal threshers handled by 2 persons $+3-4$ women who deal with the collect and the transport of paddy grain to the area of drying. The farmers carry out sorting using traditional sieve then apply mechanized winnowing (Fig. 2). Thresher JEP combines both, threshing and winnowing.

Ghana: Food sufficiency rate for cereals and legumes in Ghana is $51 \%$ while rice is $41 \%$. This low rate is largely attributed to high postharvest losses at $30 \%$ rate and low level of mechanization adoption in the country. To reduce all these challenges, government brought a policy to promote the use and acquisition of farm machinery and other agroprocessing equipment like threshers. Use of this threshing machine will drastically reduce drudgery, losses and improve upon the quality of threshed crops and this if widely adopted will not only improve farmers life but the country's economy as well.

Tajikistan: Tajikistan is an agrarian Country and its agriculture's contribution to the

Research article

CIndian Society for Education and Environment (iSee) gross domestic product is $22 \%$. More than $70 \%$ of the population of the country which is estimated at 7 million people lives in a countryside and agriculture is their mainstay. The main farm power used for hard works such as plowing, planting is mechanical power while harvesting and weeding is done by hand. Majority of farmers harvest their crops manually with the use of handmade simple tools. Threshing is also carried out manually where there are loss and crushing of grains that reduces quality and amount of production. Therefore the use of thresher could reduce grain losses, increase the production and improve the working conditions.

Design (IRRI, 1981).

The wind board was modified and the whole unit is joined by bolts, nuts and rivets for easy assembling and disassembling.

Performance test

Before the final test, preliminary functional test was carried out to assess the performance of every part, both at the workshop and at the field which was all successful.

\begin{tabular}{|c|c|c|c|}
\hline Region & $\begin{array}{l}\text { Type of paddy } \\
\text { farming }\end{array}$ & Site & Observations \\
\hline \multirow{3}{*}{ MARITIME } & \multirow[t]{2}{*}{ Under Irrigation } & $\begin{array}{l}\text { Mission Tové, } \\
\text { Kovié }\end{array}$ & $\begin{array}{l}\text { Project PARTAM for the } \\
\text { rehabilitation of } 360 \text { ha and the } \\
\text { arrangement of } 300 \text { ha }\end{array}$ \\
\hline & & Agoméglozou & $\begin{array}{l}\text { Project for the rehabilitation of } 90 \text { ha } \\
\text { and the arrangement of } 496.5 \text { ha }\end{array}$ \\
\hline & Under Rain fed & $\begin{array}{l}\text { Assahoun* } \\
\text { Agbatamé }^{*}\end{array}$ & Not documented \\
\hline \multirow[b]{2}{*}{ PLATEAUX } & Under Irrigation & $\begin{array}{l}\text { Amou Oblo, Kpélé- } \\
\text { Toutou, Sodo* }\end{array}$ & Not documented \\
\hline & Under Rain fed & $\begin{array}{l}\text { Kpélé Akata*, } \\
\text { Ablevé }\end{array}$ & Not documented \\
\hline \multirow[b]{3}{*}{ CENTRALE } & \multirow[t]{3}{*}{ Under Rain fed } & Tchakaoude & Potential of 100 ha \\
\hline & & Tchévé & Potential of 20 ha \\
\hline & & Kadjoworou* & 10 ha exploited out of 30 ha \\
\hline \multirow{6}{*}{ KARA } & Under Irrigation & $\begin{array}{l}\text { Agbang, } \\
\text { Tchamoro } \\
\text { Kabou }\end{array}$ & $\begin{array}{l}\text { Potential of } 50 \text { ha including } 6.5 \text { ha } \\
\text { used } \\
\text { Potential of } 150 \text { ha }\end{array}$ \\
\hline & \multirow[t]{5}{*}{ Under Rain fed } & Djabakou* $^{*}$ & Potential of 100 ha \\
\hline & & Possao & $\begin{array}{l}\text { Potential of } 1000 \text { ha including } 100 \\
\text { ha cleared and } 30 \text { ha ploughed } \\
\text { since } 1997\end{array}$ \\
\hline & & Tchitchira & Potential of 300 ha cleared \\
\hline & & Bidjande & $\begin{array}{l}\text { Potential of } 30 \text { ha including } 10 \text { ha } \\
\text { have ploughed since } 1979\end{array}$ \\
\hline & & M'Boratchika & $\begin{array}{l}\text { Potential of } 300 \text { ha including } 30 \text { ha } \\
\text { ploughed since } 1996 \text {. Clearing and } \\
\text { ploughing carried out by the } \\
\text { Northern project Togo ( } 300 \text { ha) }\end{array}$ \\
\hline \multirow[t]{3}{*}{ SAVANES } & Under Irrigation & $\begin{array}{l}\text { Tantiégou, } \\
\text { Kombeloti* }^{*}\end{array}$ & $\begin{array}{l}\text { Potential of } 200 \text { ha extensible to } \\
300 \text { ha }\end{array}$ \\
\hline & \multirow[t]{2}{*}{ Under Rain fed } & Simtoti* $^{*}$ & 40 ha exploited \\
\hline & & Nawakasso & $\begin{array}{l}\text { Potential of } 120 \text { ha including } 75 \text { ha } \\
\text { cleared by the Project Namiélé }\end{array}$ \\
\hline
\end{tabular}
2008-2009 of the Ministry for Agriculture, Livestock and Fishery (MAEP) in Togo
"Low cost paddy thresher" http://www.indjst.org
Azouma et al. Indian J.Sci.Technol. 
The thresher (Fig. 3), called JEP type was developed based on the existing thresher designed by IRRI (Table 2) Procedure: After the test in the field, samples of paddy were collected and analyzed in the laboratory to determine the threshing capacity and accuracy. Three (3) drum speeds were used with an air speed of $4 \mathrm{~m} / \mathrm{s}$. A ten (10) $\mathrm{kg}$ of the reaped paddy was weighed for each test, and for each speed, three tests were conducted. Grain from the grain outlet was collected during the threshing operation for five (5) seconds as well as chaff from the chaff straw outlet and the oscillating screen was also collected (National Test Code of BRAIN).

Conditions: a) Prime mover condition: The prime mover used for the performance test was the Yanmar engine with characteristics shown in the Table 3. b) Crop conditions: The paddy used for the performance test was wet paddy reaped from the field with a moisture content of $21 \%$ and $76 \%$ for straw of IR28 rice variety (Table 4 ). The length of reaped paddy is $90 \mathrm{~cm}$ and the grain shattered force measured by the TR II is $1.4 \mathrm{~N}$. c) Machine

Fig. 1. Traditional post-harvest process in West Africa

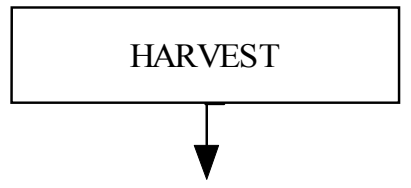

Sheaves of paddy (Moisture of grain: 20-26\%)

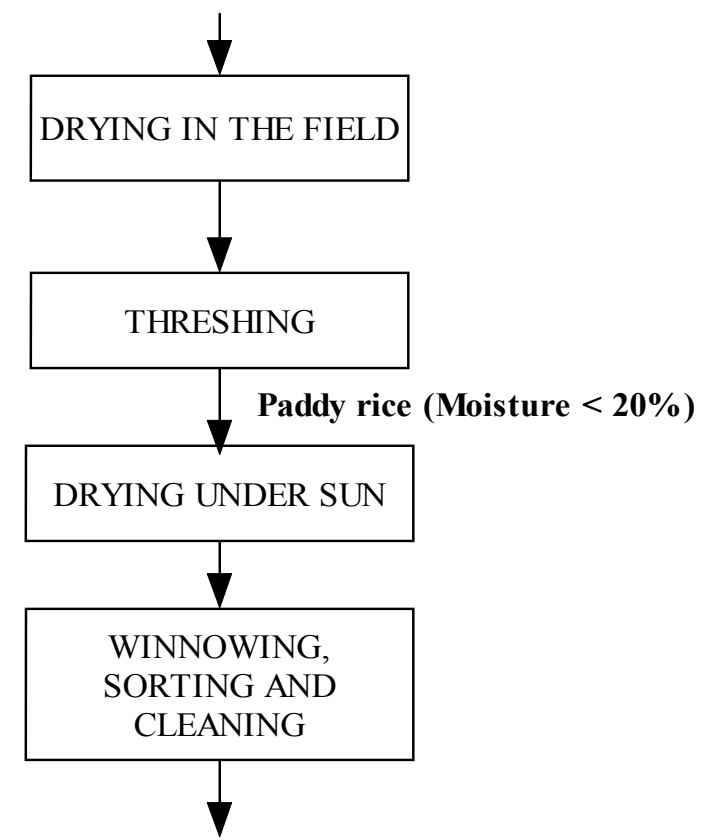

Grain paddy rice (Moisture $<\mathbf{1 5 \%}$ )

conditions: As explained in the procedure, the drum speed was set at $870 \mathrm{rpm}, 970 \mathrm{rpm}$ and $1050 \mathrm{rpm}$ as shown in Table 5. After several search for a suitable air speed, $4 \mathrm{~m} / \mathrm{s}$ was set by opening and closing of the blower window.

Results and discussion

The Fig. 4 shows that the output capacity of the thresher JEP decreased as well as the speed increased to $21 \mathrm{~m} / \mathrm{s}$. This could be due to low experience of the operator. At $23 \mathrm{~m} / \mathrm{s}$ the output capacity attained 350 $\mathrm{kg} / \mathrm{hr}$. This will be more if we improve the speed of the

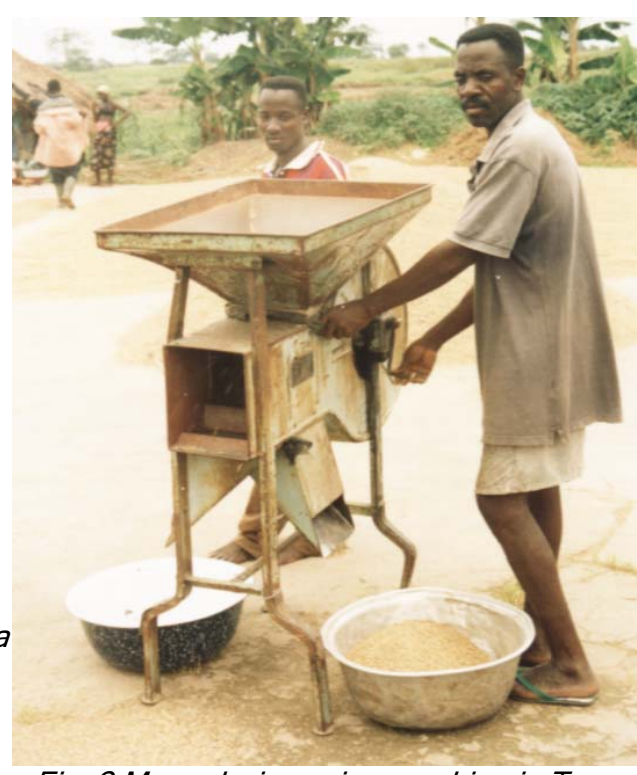

Fig. 2.Manual winnowing-machine in Togo feeding and reduce the moisture of the paddy rice.

The distribution of grain shown in the Table 6 indicates that at $19 \mathrm{~m} / \mathrm{s}$, whole grain from the grain outlet was high $(80 \%)$ but decreased when the speed was increased to $23 \mathrm{~m} / \mathrm{s}$ at $70 \%$. For the upper outlet for chaff, grain losses were minimal and nearly same for each of the speed. At the lower outlet for chaff, losses went up as speed increased. The percentage of scattered grain was nearly the same $(18 \%)$ for all the speed set. The grains collected from the

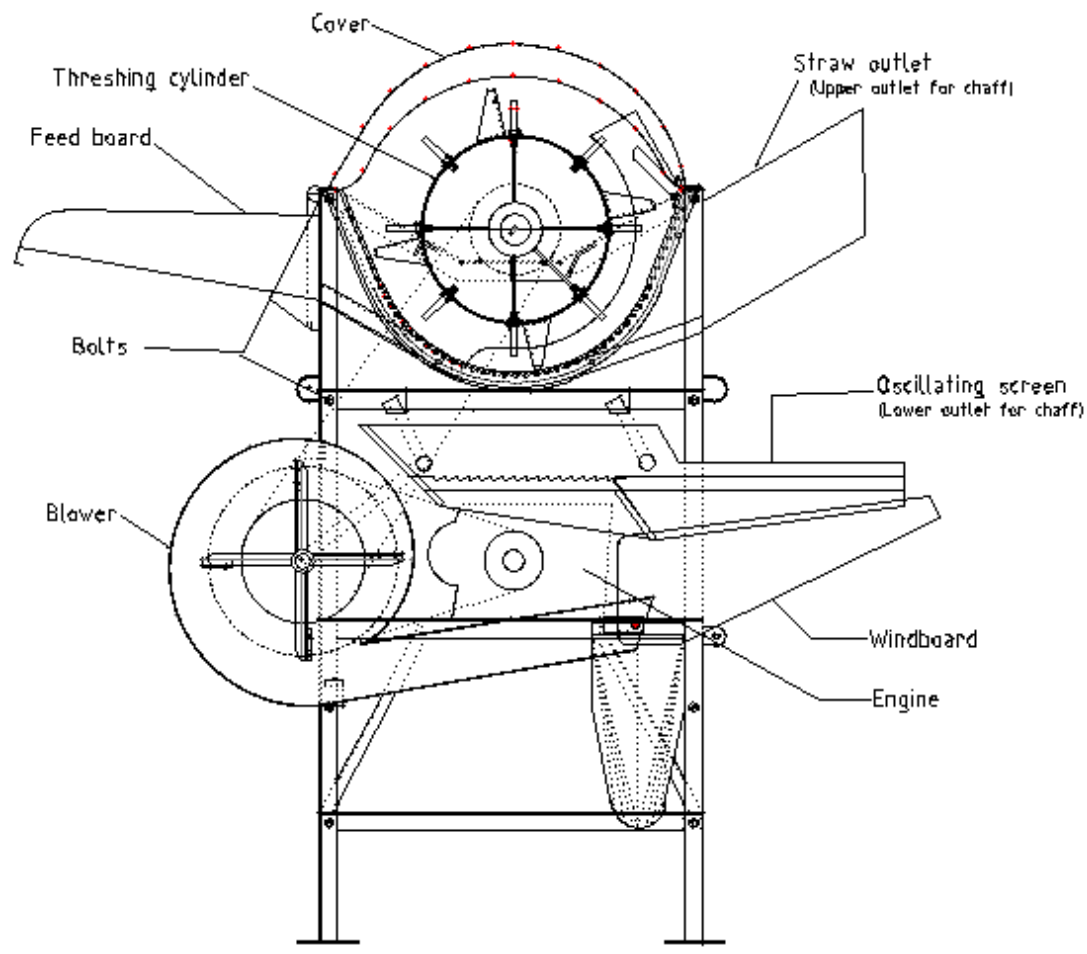

Fig. 3. Thresher JEP

grain outlet contained nearly $99 \%$ of the whole grain for all speed set (Table 7).
Research article

CIndian Society for Education and Environment (iSee)
"Low cost paddy thresher" http://www.indjst.org
Azouma et al. Indian J.Sci.Technol. 
Indian Journal of Science and Technology

Table 2. Thresher JEP specifications

\begin{tabular}{|c|c|c|c|}
\hline \multicolumn{3}{|c|}{ Main parts of the threshing machine } & Dimension \\
\hline \multirow{3}{*}{ Main frame } & Length & $\mathrm{mm}$ & 782 \\
\hline & Width & $\mathrm{mm}$ & 634 \\
\hline & Height & $\mathrm{mm}$ & 1.255 \\
\hline \multirow[t]{2}{*}{ Drum } & Length & $\mathrm{mm}$ & 705 \\
\hline & Diameter (including teeth) & $\mathrm{mm}$ & 430 \\
\hline \multirow[t]{3}{*}{ Concave } & Half circular & $\mathrm{mm}$ & 890 \\
\hline & Length & $\mathrm{mm}$ & 550 \\
\hline & Rod diameter & $\mathrm{mm}$ & 560 \\
\hline \multirow[t]{3}{*}{ Top cover } & Half circular & $\mathrm{mm}$ & 820 \\
\hline & Length & $\mathrm{mm}$ & 730 \\
\hline & Width & $\mathrm{mm}$ & 630 \\
\hline \multirow[t]{2}{*}{ Feed pan } & Length & $\mathrm{mm}$ & 725 \\
\hline & Width & $\mathrm{mm}$ & 510 \\
\hline \multirow[t]{3}{*}{$\begin{array}{l}\text { Oscillating } \\
\text { screen }\end{array}$} & Length & $\mathrm{mm}$ & 870 \\
\hline & Width & $\mathrm{mm}$ & 528 \\
\hline & Stroke & $\mathrm{mm}$ & 4.8 \\
\hline \multirow[t]{2}{*}{ Blower } & Diameter & $\mathrm{mm}$ & 440 \\
\hline & Length & $\mathrm{mm}$ & 540 \\
\hline \multicolumn{2}{|c|}{ Weight of threshing machine } & $\mathrm{kg}$ & 146 \\
\hline
\end{tabular}

Observations and comments

During the test, we noticed the followings:

- the chaff and the grain on the oscillating screen were moving towards one side;

- there were some losses from the chaff outlet lower when the drum speed was high;

- the oscillating spring got broken during the test;

- also at $21 \mathrm{~m} / \mathrm{s}$, the threshing output capacity decreased, this could be due to reasons mentioned in the results and discussions.

\section{Modifications}

The wind board was modified to enhance easy collection of grains from the screen into the grain outlet chute by increasing the length of the board with an additional metal sheet (Fig. 5). Bolts and rivets were also

Table 3. Prime mover characteristics

\begin{tabular}{|l|l|c|}
\hline Engine & Model & Weight \\
\hline $4.0 \mathrm{ps} / 2400 \mathrm{rpm}$ & MA4B Yanmar & $55 \mathrm{~kg}$ \\
\hline
\end{tabular}

Table 4. Average values of the rice IR28 crop conditions

\begin{tabular}{|c|c|c|}
\hline Items & \multicolumn{2}{|c|}{ Values } \\
\hline Moisture (\%) & Grain & $21.2(0.39)^{\star}$ \\
\cline { 2 - 3 } & Straw & $76.1(2.09)$ \\
\hline $\begin{array}{c}\text { Length of reaped } \\
\text { paddy }(\mathrm{cm})\end{array}$ & & 90.30 \\
$(11.027)$ \\
\hline $\begin{array}{c}\text { Grain shattered } \\
\text { force (N) }\end{array}$ & $1.35(0.448)$ \\
\hline \multicolumn{2}{|c|}{ * Parenthesis stands for $\pm S D$} \\
\hline
\end{tabular}

Table 5. Threshing drum speed

\begin{tabular}{|l|l|l|l|l|}
\hline $\begin{array}{l}\text { Speed } \\
\text { without } \\
\text { load }\end{array}$ & $\mathrm{m} / \mathrm{s}$ & 19 & 21 & 23 \\
\cline { 2 - 5 } & $\mathrm{RPM}$ & 870 & 970 & 1050 \\
\hline $\begin{array}{l}\text { Speed } \\
\text { with } \\
\text { load }\end{array}$ & $\mathrm{m} / \mathrm{s}$ & 18 & 20.6 & 21.7 \\
\cline { 2 - 5 } & RPM & 835 & 950 & 1000 \\
\hline
\end{tabular}

the extension of the thresher JEP in undertaken. This project involved the researchers of Université de Lomé in Togo and the local equipment manufacturer, "UPROMAH". Regarding the small scale farmers' conditions and the results of the design and the technical test of the thresher JEP, we recommend that the side edge cover of the sieve/grain pan should be raised to avoid falling of grain and chaff into the grain outlet; more tests should be conducted to ascertain why there was a decrease in threshing capacity as speed went up; the screen spring should be doubled to avoid future breakages; very wet paddy, moisture up to $21 \%$ should not be used as it stuck and does not allow
Research article

CIndian Society for Education and Environment (iSee)
"Low cost paddy thresher" http://www.indjst.org
Azouma et al. Indian J.Sci.Technol. 
free exit of chaff; more different rice varieties under different conditions should be used for future test; the research team should focused on designing a low-cost thresher.

Acknowledgement

This study was carried out with the technical and financial support of JICA-TBIC (Japan) and Université de Lomé (Togo). The authors are grateful to the assistance of Mr. SASAGE of JICATBIC (Japan) and appreciate the participation of Mr. Mumuni Eliasu, Ministry of Food and Agriculture, Agricultural Engineering Dept., Ghana and Mr. Mirakilov Jamshed Hamzaech, Tajik Agrarian Univ., Dept. of Machine Repairs \& Metal Technology, Tajikistan.

References

1. Association pour le Développement de la Riziculture en Afrique de l'Ouest (ADRAO) (2005) Verdissement du Sahel: technologies améliorées pour la riziculture irriguée. $F:$ Esprit ADRAO - Centre du riz pour l'Afrique, Septembre Décembre 2005, Numéro 10, from http://www.warda.org/ newsletter/no\%2010/ greening.fr.htm.

2. Agricultural Machinery. RNAM Test Codes and Procedure for Farm Machinery (Power Grain Threshers), Technical Series No 12.

3. Akintayo I, Cissé B and Zadji DL (2008) Guide pratique de la culture des NERICA de plateau. Centre du riz pour l'Afrique (ADRAO/WARDA), Cotonou.

4. Anonymous (1996) Caractéristiques structurelles de l'agriculture togolaise, Rapport principal, Ministère de l'Agriculture, de l'Elevage et de la pêche du Togo.

5. Anonymous (1998) Ministère de l'Agriculture et des Ressources Animales, Burkina Faso Enquête Nationale de Statistiques Agricoles 1993, Rapport général.

6. Baris P, Zaslvasky J, Perrin S (2005) La filière riz au Mali:

Fig. 5. Modified wind board: a) outside and b) inside
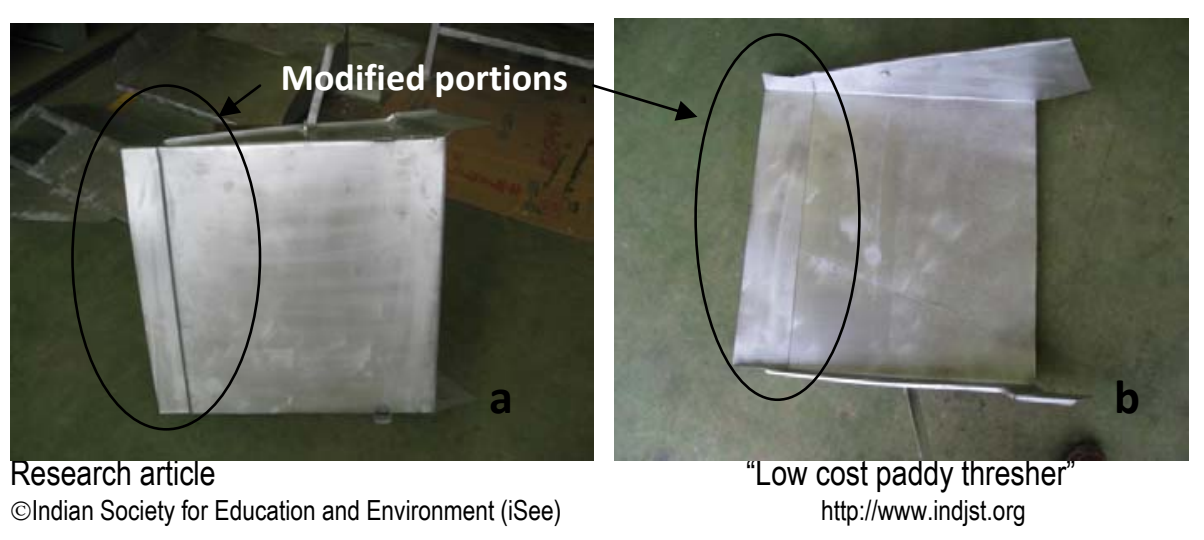
petites et moyennes exploitations. ITDG, GRET et CTA Saint-Etienne, Impressions DUMAS.

14. International Rice Research Institute (IRRI) (1981) Drawing and Test Standard Paper of Throw-in Type thresher.

15. Institut Togolais de Recherche Agronomique (ITRA) (2007) Situation de référence sur les principales céréales cultivées au Togo: Mais - Riz - Sorgho - Mil.

16. Ministère de l'Agriculture, de l'Elevage et de la Pêche (MAEP) (2008) Stratégie de la relance de la production agricole. Plan d'actions d'urgence, période 2008-2010. Ministère de l'Agri., de l'Elevage et de la Pêche du Togo.

17. Phillip DOA (1993) Aspects économiques de la traction animale au Nigeria: aperçu de la situation. In: FAO, Energie humaine et animale dans la production agricole, Actes de l'Atelier, pp: 128-131. Harare, Zimbabwe 18-22.

18. Pirot R (1998) La motorisation dans les cultures tropicales. CIRAD, pp: 43-75.

19. Sims GB and Kienzle J (2006) Farm power and mechanization for small farms in sub-saharan Africa. FAO, pp: 5-10. 